\title{
КОНСТАНТИ ЕЛЕКТРОННОГО УРЯДУВАННЯ В СУЧАСНІЙ ДОКТРИНІ КОНСТИТУЦІОНАЛІЗМУ
}

\author{
РОМАНЧУК Ольга Захарівна - здобувач кафедри конституційного права та \\ порівняльного правознавства ДВНЗ «Ужгородський національний університет»
}

DOI:10.32782/NP.2020.1.2 УДК 342.727

\begin{abstract}
У статті розглядаються основні положення бункиіонування системи електронного урядування на сучасному етапі розвитку демократичних процедур. Доведено, що електронне урядування - це нове явище, яке покрашує надання державних послуг громадянам, покрашує ефбективність роботи державного сектору та збагачує політичну відкритість, та пов'язану з нею легітимність влади. Визначено наступні константи електронного врядування.
\end{abstract}

Належне інформаційне забезпечення управлінсъкої діяльності, шо має бути спрямоване на гарантування отримання інформацй адресатами в обсязі, в межах та у строки, достатні для якісного виконання функиій, покладених чинним законодавством на суб'єктів інбормачійних правовідносин.

Дуальність комунікації , яка породжує новий соціально- правовий капітал, котрий спрямований надати можливість людям та групам будувати довіру $і$ прачювати разом 3 урядами, що сприяє стимулюванню творчого рішення проблем, з якими стикаються уряди та громади, дає можливість розширити виробничі та споживчі потоки. Вказано, що використання додатків та інструменти Web 2.0 дозволяють веб-сайтам уряду бути менш однонаправленими в обміні інформацією та більше підтримувати інтерактивну взаємодію та участь своӥх користувачів.

Багаторівневість та широкопрофбільність системи електронного урядування. Вказано, що важливо, щоб на місцевому рівні илени територіальної громади на локальному рівні мали вільний доступ до інтернет-спільнот, що забезпечує участь місиевого населення у забезпеченні своєї життедіяльності, а також щзоб урядування пропонувало широкий ряд послуг у різних сферах суспільного життя.

Інформаційна грамотність населення. Комп'ютерна грамотність громадян виступає важливим елементом впровадження електронного врядування $і$ для підвищення їірівня саме держава повинна втілювати широкий комплекс заходів.

Популяризація електронного урядування. Досвід багатьох держав, щзодо впровадження врядування, що незалежно від розвиненості краӥни та їі інформаиійних мереж доводить потребу активного маркетингового впровадження їх можливостей.

Ключові слова: електронне урядування, публічна влада, відкритість влади, конституизоналізм.

\section{Постановка проблеми}

Наші соціальні реалії та майбутнє переплітаються з цифровими технологіями, що вимагають нових підходів до вирішення викликів участі громади, соціальної мобільності, роботи, дозвілля, освіти та розваг. Адаптація до цифрових середовищ, що швидко змінюються, забезпечує безпрецедентні можливості для переосмислення свого майбутнього, дають можливість знайти нові рішення проблем та функціонування владного апарату в різних аспектах життя. «В усьому світі уряди намагаються перетворити своє суспільство 3 широким використанням ін- 


\section{Теорія, історія держави і права, конституційне право}

формаційно-комунікаційних технологій»[1, p.1327]. Стало очевидним, що урядам країн у всьому світі потрібно стати більш прозорими в їх процесах, щоб уникнути корупції та захистити права особи, що спричинило потребу в більшій кількості стратегій залучення громадян і більш глибоке вивчення відкритих урядових рамок.

Електронне урядування - це нове явище, яке покращує надання державних послуг громадянам, покращує ефективність роботи державного сектору та збагачує політичну відкритість, та пов'язану з нею легітимність влади. Поліпшення ефективності роботи державного сектора є важливим аспектом переваг електронного уряду та вирішує вимоги щодо скорочення видатку державного бюджету. Європейський рівень конституціоналізму дозволяє говорити про потребу наявності стандартів для реалізації принципу відкритості діяльності влади.

\section{Стан дослідження}

Проблемами удосконалення діяльності органів державної влади, легітимність та відкритість публічного управління, реформування та демократизація публічно-правової сфери завжли є під пильною увагою науковців в Україні. Слід відзначити значні доробки таких науковців як Ю. Бисаги, О. Дніпров, I. Жаровської, В. Ковальчука, О. Лізунової та багатьох інших. Однак зміни в інформаційній сфері вимагають додаткового аналізу аспектів практичного впровадження електронного урядування як ефективного механізму демократизації політикоконституційної реальності.

Метою цієї статті $є$ визначення основних констант електронного урядування в сучасній доктрині конституціоналізму.

\section{Виклад основних положень}

На нашу думку, впровадження механізму електронного врядування в Україні потребує теоретичного аналізу основних необхідних постійних елементів(констант), які слід вважати основними чинниками функціонування електронного урядування. До них відносимо наступні.
Належне інформачійне забезпечення управлінсъкої діяльності. Як визначають провідні науковці, під інформаційним забезпеченням розуміється «діяльність, організована в межах управління і спрямована на проектування, функціонування й удосконалення інформаційних систем, які забезпечують ефективне розв'язання завдань управління» [2, с. 148]. Також цитований автор вказує, що вказує, «з позицій теорії управління інформаційне забезпечення має бути спрямоване на гарантування отримання інформації адресатами в обсязі, в межах та у строки, достатні для якісного виконання функцій, покладених чинним законодавством на суб’єктів інформаційних правовідносин».

Дуальність комунікащії. Інструменти Web 2.0, такі як блоги, Twitter, Facebook та вікі для спільної роботи, можуть принести користь як уряду, так і громадянам, сприяючи внутрішній та зовнішній участі, покращуючи стосунки та покращуючи прийняття. Незалежно від того, чи використовує урядовий веб-сайт інструменти Web 2.0 або більш традиційні форми (вікна онлайн-чату та коментарів), або обидва - вказане є демонстрацією існування ключової стратегію - сприяння взаємодії між громадянами та урядом та іншими установами, такими як інші рівні влади та неурядові групи.

Група турецьких науковців на чолі з М. Йілдіз аналітично довели, що потенційні адміністративні та політичні вигоди від впровадження електронного уряду пропорційно залежать від зручності використання цих додатків [3, р.966].

Незважаючи на те, що риторика співпраці згори вниз не може знайти позитивного відгуку громадян, підхід знизу вгору має більший успіх, оскільки соціальні медіа, цифрові можливості та електронна пошта $є$ прикладами взаємодії громадян та участі громадян. Комунікація породжує новий соціально- правовий капітал, котрий спрямований надати можливість людям та групам будувати довіру і працювати разом з урядами, що сприяє стимулюванню творчого рішення проблем, з якими стикаються уряди та громади, дає можливість розширити виробничі та споживчі потоки. 
Один із способів втілення цієї риторики в дію - через урядові веб-сайти. Більшість урядів використовують домашню сторінку веб-сайту або веб-портал як інтегрований шлюз для обміну інформацією та послугами. В останні роки, однак, додатки та інструменти Web 2.0 дозволяють веб-сайтам уряду бути менш однонаправленими в обміні інформацією та більше підтримувати інтерактивну взаємодію та участь своїх користувачів [4, с.334]. Таким чином, веб -сайти електронного уряду розвиваються та адаптуються завдяки розвитку інформаційних технологій.

Багаторівневість та широкопрофільність системи електронного урядування. Комунікаційна стратегія, яка використовує кілька каналів, принесе користь уряду, бізнесу та громадянам. Однак урядові веб-сайти потрібно регулярно оновлювати, щоб мати значення. Окрім урядових каналів, розповсюдження цифрових технологій, особистих веб-сайтів, блогів, форумів, вікі, соціальних та професійних мереж та акаунтів y Twitter також важливо, щоб на місцевому рівні члени територіальної громади на локальному рівні мали вільний доступ до інтернет-спільнот, що забезпечує участь місцевого населення у забезпеченні своєї життедіяльності.

Децентралізація передбачає вектор змін в державному секторі через прагматичне поєднання адміністративних, фіскальних та політичних змін, які дозволять органам місцевого самоврядування нести відповідальними за надання послуг, за ефективне управління фіскальною службою та поведінку персоналу. I ці зміни в сприйнятій відповідальності потім матимуть вплив на ефективність та справедливість аспектів надання послуг. Реформа децентралізації виправдані 3 політичного, економічного та соціального розвитку, тому для досягнення таких бажаних результатів важливо зосередити увагу на адміністративно-технічному потенціалі, необхідному для функціонування регіональних органів влади. Особливо це стосується рівня влади, який $є$ найближчим до місцевих громад - місцевого самоврядування. Державні службовці, які працюють в органах місцевого самоврядування, повинні ефективно та ефективно функціонувати в своїх організаціях та громадах, а також у багаторівневій системі управління, до складу якої вони входять. Продуктивність системи та їі здатність досягти запланованих результатів сильно визначається тим, як структурується, мотивується та ресурсується людський капітал. Постійне та цілеспрямоване професійне навчання має вирішальне значення для розвитку та розбудови потенціалу.

Аналіз позитивного європейського досвіду та прогресивних технологій вказує на те, що громадяни не схильні співпрацювати 3 владою на найвищому рівні, проте кількість громадян, які активні в комунікації 3 місцевими органами влади та самоврядування є набагато вижчою. Аінн Мандарано, Махбубур Мієнар, Крістофер Штейнс вказують, що більшу активність громадян на місцевому рівні можна пояснити недовірою громадян урядові [5]. Проте, ми вважаємо, що можливо існує і інша причина - локальні органи вирішують питання, які актуальніші для пересічної особи, ніж загальні стратегії розвитку.

Важливо також, щоб урядування пропонувало широкий ряд послуг у різних сферах суспільного життя. Наприклад, Чикаго пропонує своїм громадянам 281 публічний сервіс, розподілений на 256 сфер, a Curitiba 508 публічних послуг, розподілених по 26 сфер [6, с.1452].

Інформащійна грамотність населення. Незважаючи на обіцянку цифрового майбутнього, певна неактивність або відсутність реальних механізмів участі через використання новітніх технологій продовжують залишатися проблемою. Комп'ютерна грамотність громадян виступає важливим елементом впровадження електронного врядування. До участі можуть входити люди, які регулярно користуються цифровою системою технології у повсякденному житті, але які не обізнані та кваліфіковані в тому, щоб дозволити їм повну та справедливу участь у громаді чи в цифровій економіці. Цифрова неучасть може загрожувати соціальним та сімейним зв'язкам, доступу до основних послуг, таких як банківська справа та освіта, зменшили перспективи працевлаштування. 


\section{Теорія, історія держави і права, конституційне право}

Цифрове громадянство - це широкий термін, який охоплює багато аспектів участі та поведінки в Інтернеті, включаючи цифрову обізнаність, етичні кодекси поведінки, політичну активність, особисті та інтереси, орієнтовані на інтереси.

Для підвищення рівня інформаційної грамотності Уряд України пропонує комплекс заходів. Так п. Плану заходів з реалізації Концепції розвитку електронного урядування в Україні, що затверджений розпорядженням Кабінету Міністрів України від 22 серпня 2018 р. № 617-р вимагає від МОН, Мінекономрозвитку, Мінкультури, Укрдержархів, Державне агентство $з$ питань електронного урядування за 2018-2020 роки 3 сприяти підвищенню готовності суб'єктів звернення до отримання електронних послуг шляхом забезпечення:

розвитку відповідних електронних освітніх ресурсів та розроблення індивідуальних модульних навчальних програм різних рівнів складності;

створення спеціальних місць для навчання громадян на базі мережі бібліотек, архівів, громадських об'єднань;

розвитку системи дистанційного навчання, у тому числі для осіб з особливими освітніми потребами [7].

Аналіз веб-сайтів органів публічної влади різних рівнів, електронних ресурсів вищевказаних зобов'язаних суб'єктів, нажаль, не дав нам можливості отримати доступ до модульних навчальних програм для громадськості для підвищення інформаційної грамотності.

Популяризація електронного урядування. Досвід багатьох держав, щодо впровадження врядування, що незалежно від розвиненості країни та іiі інформаційних мереж доводить потребу активного маркетингового впровадження їх можливостей. Як вказує I. Жаровська «формування громадянського суспільства та заохочення громадської активності визнано пріоритетним завданням суспільнополітичного розвитку» [8, с. 242].

Досвід інших держав може вказувати на незначну активність громадськості. Наприклад, репрезентативний є досвід Шрі-Аанки щодо електронного уряду - "SMART People SMART Island”, який діє в державі вже біль- ше пятирічного терміну. Проте рівень споживання послуг електронного уряду громадянами Шрі-Аанки становить 22,3\%. Дослідження проведене ООН, підкреслило, що 77,7\% громадян не знають про послуги електронного уряду в Шрі-Аанці, тому кофіцієнт електронними послугами є дуже низьким. Однак уряд щорічно інвестує понад 2000 мільйонів рупій (приблизно 2, 7 млн доларів СШІА - виділено нами - О. Романчук) для впровадження електронного уряду [9, c. 1932].

\section{Висновок}

Електронне урядування - це нове явище, яке покращує надання державних послуг громадянам, покращує ефективність роботи державного сектору та збагачує політичну відкритість, та пов'язану з нею легітимність влади. Визначено наступні константи електронного врядування: нНалежне інформаційне забезпечення управлінської діяльності, що має бути спрямоване на гарантування отримання інформації адресатами в обсязі, в межах та у строки, достатні для якісного виконання функцій, покладених чинним законодавством на суб'єктів інформаційних правовідносин; дуальність комунікації, яка породжує новий соціально-правовий капітал, котрий спрямований надати можливість людям та групам будувати довіру та підтримувати інтерактивну взаємодію та участь своїх користувачів; багаторівневість та широкопрофільність системи електронного урядування, що передбачає впровадження механізму електронного врядування на всіх рівнях, включаючи локальний, а також наявність широкого ряду послуг у різних сферах суспільного життя; інформаційна грамотність населення; популяризація електронного урядування.

\section{лiтepaтypa}

1. Charlene M. L. Roach and Cristal Beddeau. Engaging Citizens and Delivering Services, Open Government. 2020. P. 1327-1347) doi: 10.4018/978-1-5225-9860-2.ch062.
2. Петьовка
B.B.
Надання адміністративних послуг в Україні: теорія і практика: монографія; ред. А. О. Селіванов. Київ: Аогос, 2014. 213 с. 
3. Yildiz M., Ocak N., Yildirim C., Cagiltay K., Babaoglu C. Usability in Local E-Government: Analysis of Turkish Metropolitan Municipality Facebook Pages Open Government: Concepts, Methodologies, Tools, and Applications. 2020. P. 966 - 984

4. Dezuanni M., Foth M., Mallan K., Hughes H. Digital Participation through Social Living Labs.London: Chandos Publishing. 2018. 382 p.

5. Mandarano L., Meenar M., Steins Ch. Building Social Capital in the Digital Age of Civic Engagement Journal of Planning Literature. 2010. V.: 25 issue: 2, p. 123-130 https://doi. org/10.1177/0885412210394102

6. Alcides Rezende D. Digital City Projects: Information and Public Services Offered by Chicago (USA) and Curitiba (Brazil) Open Government: Concepts, Methodologies, Tools, and Applications. 2020. P. 1452- 1468

7. План заходів 3 реалізації Концепції розвитку електронного урядування в Україні: затв. розпорядженням Кабінету Міністрів України від 22 серпня 2018 p. № 617-p URL: https://www.kmu.gov.ua/ npas/pro-zatverdzhennya-planu-zahodiv-zrealizaciyi-koncepciyi-rozvitku-elektronnogouryaduvannya-v-ukrayini

8. Жаровська I. М. Генезис ідеї відкритості влади Форум права. 2009. № 3. С. 242246.

9. Sufna N., R. Lalitha S. Fernando Public Value of E-Government: The Case of Ministry of Public Administration and Home Affairs in Sri Lanka. Open Government: Concepts, Methodologies, Tools, and Applications. 2020. P. 1932-1952.

Romanchuk O.Z. Postgraduate of constitutional and comparative law department of "Uzhgorod National University"

THE CONSTANTS OF E-GOVERNMENT IN THE MODERN DOCTRINE OF CONSTITUTIONALISM

The article deals with the basic provisions of functioning of the e-government sys- tem at the present stage of development of democratic procedures. E-government has been proven to be a new phenomenon that improves public service delivery to citizens, improves public sector efficiency, and enhances political openness and the legitimacy of government. The following e-government constants are defined.

Adequate information support of management, which should be aimed at ensuring that information is received by the addressees in an amount, within a time frame, and is sufficient for the qualitative performance of the functions assigned by the current legislation to the subjects of the legal relationship.

The duality of communication, which generates new social and legal asset, aimed at empowering people and groups to build trust and work with governments, which helps to stimulate creative solutions to the problems faced by governments and communities, enables them to expand their productive and consumer flows. Applications and Web 2.0 tools are said to allow government websites to be less unidirectional in sharing information and more supportive of interactive interaction and participation of their users.

Multilevel and wide-ranging of e-government system. It is stated that it is important at the local level that members of the territorial community at the local level have free access to internet communities, which ensures the participation of local people in providing their livelihoods, and the government offers a wide range of services in various spheres of public life.

Information literacy of the population. Computer literacy of citizens is an important element of the implementation of e-government and in order to increase its level it is the state itself that should implement a wide range of measures.

Promoting e-government. The experience of many countries regarding the implementation of governance, which, regardless of the development of the country and its information networks, proves the need for active marketing of their capabilities. 